\title{
特集 急性期血栓回収療法
}

原 著

\section{0 歳以上の高齢者に対する急性期血栓回収術の治療転帰}

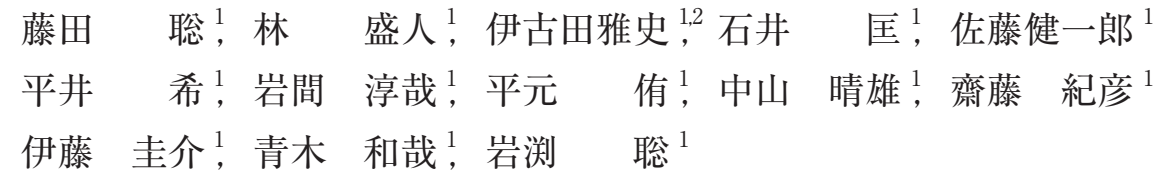

\section{Outcome of Mechanical Thrombectomy for Acute Ischemic Stroke in Patients Aged over 80 Years}

Satoshi Fujita, M.D. ${ }^{1}$, Morito Hayashi, M.D. ${ }^{1}$, Masashi Ikota, M.D. ${ }^{1,2}$, Masashi IshII, M.D. ${ }^{1}$, Kenichiro Sato, M.D. ${ }^{1}$, Nozomi Hirai, M.D. ${ }^{1}$, Junya Iwama, M.D. ${ }^{1}$, Yu Hiramoto, M.D. ${ }^{1}$, Haruo Nakayama, M.D. ${ }^{1}$, Norihiko SAITo, M.D. ${ }^{1}$, Keisuke Ito, M.D. ${ }^{1}$, Kazuya Aoki, M.D. ${ }^{1}$, and Satoshi IwABUCHI, M.D. ${ }^{1}$

${ }^{1}$ Department of Neurosurgery, Toho University Ohashi Medical Center, Tokyo, and ${ }^{2}$ Department of Neurosurgery, Jichi Medical University Saitama Medical Center, Saitama, Japan

Summary: Objective: We compared the effect of endovascular treatment for acute ischemic stroke between patients aged $>80$ years and those aged $<80$ years.

Patients and Methods: A total of 37 consecutive patients underwent mechanical thrombectomy between July 2014 and November 2016. Patients were divided into 2 groups by age, those aged $>80$ years $(\mathrm{n}=16)$ and those aged $<80$ years $(\mathrm{n}=21)$.

Results: There were no significant differences between the two groups regarding preprocedural computed tomography (CT) Alberta Stroke Programme Early CT Score (ASPECTS) (9.1 vs. 8.7), National Institutes of Health Stroke Scale (NIHSS) (20.5 vs. 19.2), and previous intravenous administration of alteplase (56.3\% vs. 61.9\%). Successful recanalization (Thrombolysis in Cerebral Infarction 〔TICI] grade $2 \mathrm{~b}, 3$ ) was achieved in $87.5 \%$ patients aged $>80$ years and $81.0 \%$ patients aged $<80$ years. However, the rate of favorable outcomes, such as modified Rankin Scale score of 0-2 at 90 days after stroke, was significantly lower in patients aged $>80$ years than in those aged $<80$ years $(12.5 \%$ vs. $52.4 \%$ ). In addition, the complication rate, including heart failure, aspiration pneumonia, and urinary infection, was much higher in patients aged $>80$ years than in those aged $<80$ years.

Conclusion: Mechanical thrombectomy is safe and effective for acute ischemic stroke, even in patients aged $>80$ years. However, the clinical outcomes in patients aged $>80$ years were poorer than those in aged $<80$ years. A higher incidence of general complications was associated with a poorer prognosis in elderly patients.
Key words:

- acute ischemic stroke

- elderly patients

- mechanical thrombectomy

Surg Cereb Stroke

(Jpn) 47: 409-413, 2019

${ }^{1}$ 東邦大学医療センター大橋病院 脳神経外科, ${ }^{2}$ 自治医科大学附属さいたま医療センター 脳神経外科(受稿日 2017.9. 18)(脱稿日 2018. 5.8) 〔連絡先：７ 153-8515 東京都目黒区大橋 2-17-6 東邦大学医療センター大橋病院 脳神経外科 藤田 聡] [Address correspondence: Satoshi FujiTA, M.D., Department of Neurosurgery, Toho University Ohashi Medical Center, 2-17-6 Ohashi, Meguro-ku,Tokyo 153-8515, Japan] 


\section{はじめに}

近年, 急性期脳梗塞治療における血栓回収術の有用性が 多く示されてお ${ }^{122) 47711)}$, 今後治療適応はますます拡大 していく可能性がある.ささらに，超高齢化社会を迎えるわ が国では，高齢者に対する血栓回収術が行われる機会は増 加していくと予想され，年齢に対する治療効果の検討は本 邦では特に重要と考えられる．今回は，80歳以上の急性 期脳主幹動脈閉塞に対する血管内血栓回収術の当院におけ る治療成績を解析し, 高齢者に対する本治療の効果と問題 点について検討した.

\section{対象と方法}

2014 年 7 月から 2016 年 11 月まで当院で急性期血栓回収 療法が行われた連続 37 例を対象とした. 80 歳以上の群と 80 歳未満の群に分け, 治療成績, 臨床経過に関して検討 した．当院では血栓回収術の適応として年齢は制限してい ない. 80 歳以上の場合は適応を発症前の modified Rankin Scale (mRS)が 2 以下である症例を原則としているが, mRS が 3 以上であっても認知症の有無, 介助の程度, 発症から の時間，患者背景などを考慮して個別に対応している，血 栓回収術を行う可能性がある場合は, 頭部 CT を施行し, 脳出血が除外された時点で, CT angiography にて血管お よびCT Alberta Stroke Programme Early CT Score(ASPECTS)を評価し，禁忌項目がないことを確認し次第，recombinant tissue plasminogen activator(rt-PA)を静注して いる．脳主幹動脈閉塞例の場合には，そのまま血管撮影室 に入室させ，血管撮影に引き続いて血栓回収術を行ってい る。使用したデバイスは主に, Trevo(Stryker Neurovascular, Mountain View, CA, USA), Penumbra System (Penumbra, Alameda, CA, USA)である。治療効果判定は Thrombolysis in Cerebral Infarction(TICI) grade, 発症か ら再開通までの時間 (Onset to Reperfusion：O2R), 発症か ら病着までの時間 (Onset to Door：O2D), 病着から大腿動 脈穿刺までの時間 (Door to Puncture：D2P), 大腿動脈穿 刺から再開通までの時間(Puncture to Reperfusion：P2R), 24 時間後の National Institutes of Health Stroke Scale (NIHSS), 入院中合併症, 退院 30 日後, 90 日後における $\mathrm{mRS}$ で評価した．統計解析にはIBM SPSS Version 21(IBM, Armonk, New York, USA) を使用した。群間比較には $\chi^{2}$ 検定，平均值の群間比較には $\mathrm{t}$ 検定，中央值の群間比較に は Mann Whitney 検定を行い, $\mathrm{p}<0.05$ を有意差ありとし た。

\section{結果}

対象患者背景を Table 1 に示す. 80 歳以上群は 16 例 (平
均年齢 $87.4 \pm 3.4$ 歳), 80 歳未満群は 21 例 (平均年齢 $66.5 \pm$ 11.8 歳)であった. 男女比は 80 歳以上群では男性 8 人, 女 性 8 人, 80 歳未満群では男性 14 人, 女性 7 人であった. 閉塞部位, 入院時平均 NIHSS, CT ASPECTS, rt-PA 投 与, TICI grade $2 \mathrm{~b}$ 以上の再開通率, O2D, D2P, P2R, O2R の経過時間については, いずれも 80 歳以上群と 80 歳未満 群との間に有意な差は認められなかった。

発症前の mRS 2 以下に関して, 80 歳以上群が 16 例中 11 例であり, 80 歳未満群 21 例中 21 例に比べて有意に少な かった $(\mathrm{p}<0.05)$. 発症 24 時間後の NIHSS は 80 歳以上群 では 17.5(5-25), 80 歳未満群では 13.7 (1-27)であり有意差 はなかったが, 80 歳以上群で高い傾向を示した $(\mathrm{p}=0.146)$. カテーテル治療に関連する合併症として, カテーテルによ る血管損傷が原因でくも膜下出血を発症した症例は 80 歳 未満群で 1 例認められ ( $4.8 \%)$, 穿刺部腫脹が 80 歳以上群 で 1 例認められた $(6.3 \%)$. カテーテル治療に関連しない 周術期合併症は, 80 歳以上群では 10 例 (62.5\%, うち心不 全 3 例, 誤嚥性肺炎 5 例, 尿路感染 2 例), 80 歳未満群で は 4 例 (19.0\%, うち心不全 1 例, 誤嚥性肺炎 1 例, 尿路 感染 2 例 $)$ と, 80 歳以上群で有意に多かった $(\mathrm{p}=0.007)$. 発症 30 日後, 90 日後における mRS を Fig. 1 に示した. 転帰良好とされる $\mathrm{mRS} 2$ 以下は 80 歳以上群では 30 日後 で 3 例 $(18.8 \%), 90$ 日後で 2 例 $(12.5 \%)$ だったのに対し, 80 歳未満群では 30 日後で 10 例 (47.6\%), 90 日後で 11 例 (52.4\%)であり, 80 歳以上群で 90 日後の良好例が有意に 少なかった $(\mathrm{p}=0.012)$. 一方, 転帰不良とされる mRS 5, 6 は 80 歳以上群では 30 日後では 4 例 $(25 \%$, うち死亡 0 例), 90 日後では 6 例 $(37.5 \%$, うち死亡 1 例), 80 歳未満 群では 30 日後では 3 例 (14.3\%, うち死亡 0 例)，90 日後 では 3 例 (14.3\%, うち死亡 1 例)であり, 有意差はないも のの 80 歳以上群で転帰不良例が多い傾向にあった $(\mathrm{p}=$ $0.103)$.

急性期治療後の経過について，30 日後と90日後の mRS の推移を評価した(Fig. 2). $\mathrm{mRS}$ が 1 以上改善した症例 は, 80 歳以上群では $12 \%$ しかみられず, 80 歳未満群では $40 \%$ でったのに対して, 統計学的に有意差はないもの の, 80 歳以上群で改善例が少なかった $(\mathrm{p}=0.08)$. 一方, $\mathrm{mRS}$ が 1 以上悪化した症例は 80 歳以上群では $19 \%$ に対 し, 80 歳未満群では $5 \%$ と, 80 歳以上群で多い傾向を示 した $(\mathrm{p}=0.175)$.

\section{考察}

高齢者に対する急性期血栓回収術については, 再開通に よる治療効果を示すものの, 良好な転帰が得られていない との報告が多いが39912), Goyal ら ${ }^{5)}$ の HERMES studyの結 果では, 各年齢層での比較において 80 歳以上の interven- 
Table 1 Basic demographic and clinical data for patients aged $>80$ years old and those aged $<80$ years

\begin{tabular}{|c|c|c|c|c|}
\hline & & $\begin{array}{l}\text { Over } 80 \text { years old } \\
\quad(n=16)\end{array}$ & $\begin{array}{l}\text { Under } 80 \text { years old } \\
(n=21)\end{array}$ & $p$ value \\
\hline Mean age & & $87.4(82-94)$ & $66.5(31-78)$ & $<0.0001^{*}$ \\
\hline Men: Women & & 8: 8 & $14: 7$ & \\
\hline \multirow[t]{2}{*}{ prestroke mRS } & $2 \geqq$ & $11(68.8 \%)$ & $21(100 \%)$ & $<0.001^{*}$ \\
\hline & $3 \leqq$ & $5(31.3 \%)$ & $0(0 \%)$ & $<0.001^{*}$ \\
\hline \multirow[t]{3}{*}{ Occlusion site } & ICA & $6(37.5 \%)$ & $9(42.9 \%)$ & 0.742 \\
\hline & MCA & $10(62.5 \%)$ & $11(52.4 \%)$ & 0.538 \\
\hline & Others & $0(0 \%)$ & $1(4.8 \%)$ & 0.376 \\
\hline NIHSS & At baseline & 20.5 & 19.2 & 0.545 \\
\hline CT ASPECTS & & 9.1 & 8.7 & 0.375 \\
\hline Treatment with t-PA & & $9(56.3 \%)$ & $13(61.9 \%)$ & 0.729 \\
\hline $\mathrm{TICl} 2 \mathrm{~b} \leqq$ & & $14(87.5 \%)$ & $17(81 \%)$ & 0.592 \\
\hline \multirow[t]{4}{*}{ Median time (min) } & $\mathrm{O} 2 \mathrm{R}$ & 209 & 246 & 0.665 \\
\hline & O2D & 49 & 65 & 0.735 \\
\hline & $\mathrm{D} 2 \mathrm{P}$ & 49 & 56 & 0.66 \\
\hline & $\mathrm{P} 2 \mathrm{R}$ & 99 & 65 & 0.08 \\
\hline NIHSS & at $24 \mathrm{~h}^{\dagger}$ & $17.5(5-25)$ & $13.7(1-27)$ & 0.146 \\
\hline Symptomatic bleeding $^{\dagger \dagger}$ & & $0(0 \%)$ & $1(4.8 \%)$ & 0.376 \\
\hline Heart failure & & $3(18.8 \%)$ & $1(4.8 \%)$ & 0.175 \\
\hline Urinary infection & & $2(12.5 \%)$ & $2(9.5 \%)$ & 0.773 \\
\hline Pneumonia & & $5(31.3 \%)$ & $1(4.8 \%)$ & $0.03^{*}$ \\
\hline
\end{tabular}

$* \mathrm{p}<0.05$

${ }^{+} \mathrm{NIHSS}$ at $24 \mathrm{~h}$ after stroke onset

${ }^{\dagger \dagger}$ Symptomatic bleeding was defined as a 1-point deterioration in level of consciousness mRS: modified Rankin Scale, ICA: internal carotid artery, MCA: middle cerebral artery, NIHSS: National Institutes of Health Stroke Scale, ASPECTS: Alberta Stroke Programme Early CT Score, t-PA: tissue-type plasminogen activator, TICl: Thrombolysis in Cerebral Infarction, O2R: Onset to Reperfusion, O2D: Onset to Door, D2P: Door to Puncture, P2R: Puncture to Reperfusion
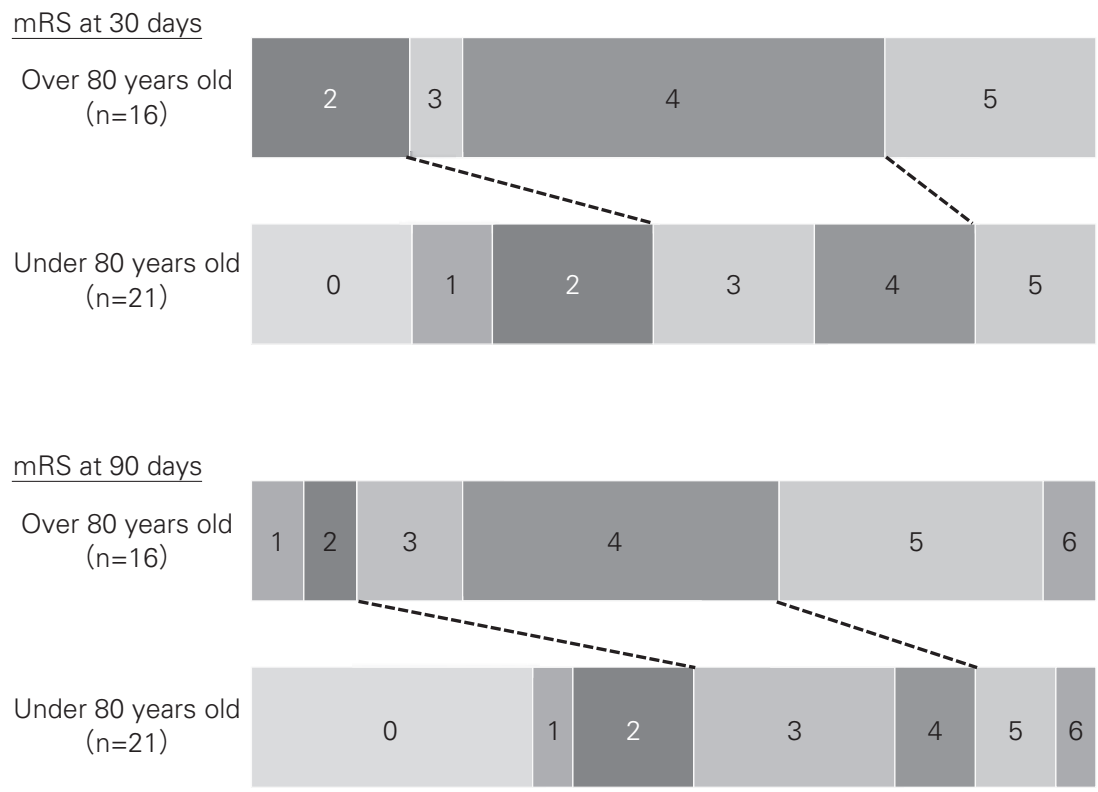

Fig. 1 Distribution of modified Rankin Scale (mRS) scores at 30 days/90 days after stroke. 

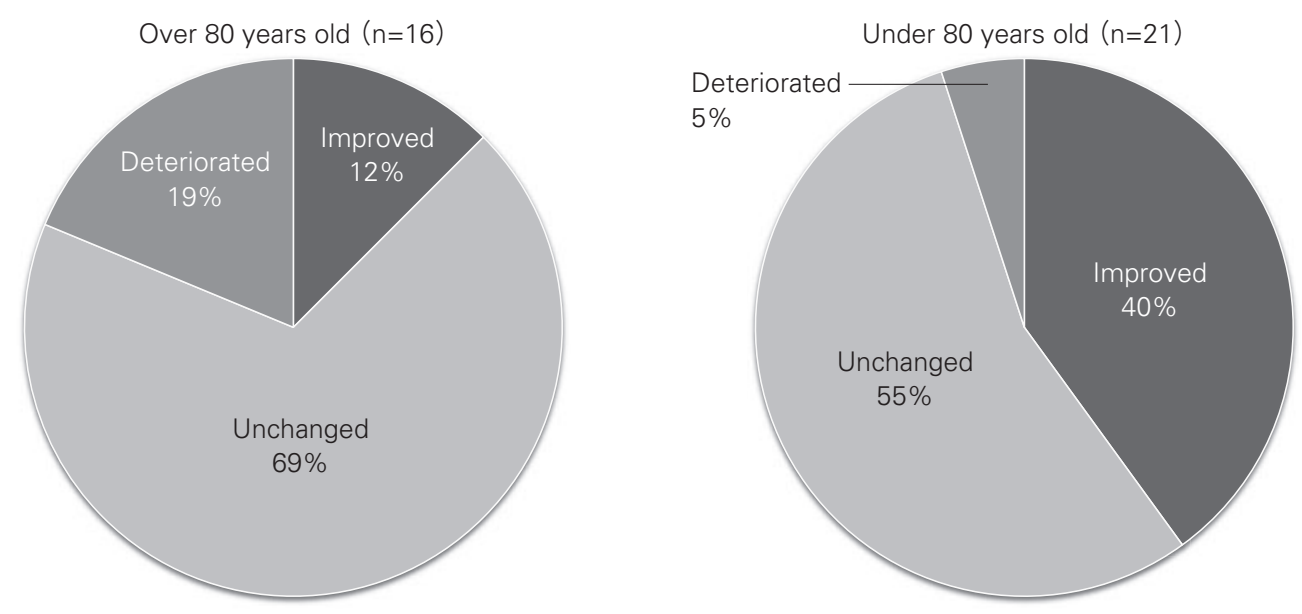

Fig. 2 Change in modified Rankin Scale (mRS) scores between the groups at 30 days/90 days. Improved: More than 1-point decrease in mRS Unchanged: No change in $\mathrm{mRS}$ Deteriorated: Increase in $\mathrm{mRS}$

tionの効果がいちばん高かったと報告している．Parrilla ら ${ }^{9)}$ は，高齢者は若年者に比べ，高血圧，心房細動，抗凝 固薬内服などが転帰不良のリスクとなること, 内頚動脈閉 塞による症例で死亡率が高いこと， 6 時間以上経過してか ら血栓回収術を行った症例では転帰が悪いことを報告して いる. Son ${ }^{12)}$ は高齢者群で転帰が悪い理由として, 発症 直後から重症であることが多いこと，再開通までの時間が 長い症例が多いことを挙げている. Cohen $ら^{3)}$ も高齢であ ること自体が死亡率を上昇させ，転帰不良因子であると報 告しており, 今回当施設に扔ける 80 歳以上と 80 歳未満と の比較においても, 発症から再開通までの時間経過に有意 な差を認めなかったものの，30 日後，90日後の転帰に明 らかな差が認められた. Hwang ら は $^{6}$ は 90 日後 mRSを評 価し，転帰良好例が $35.7 \%$ ，転帰不良例が $46.3 \%$ と報告し ており， Lima ら $^{8)}$ も転帰良好例が $29 \%$ であったと報告し ている。 これらと比較して, 当院では不良症例が少ない傾 向にあったが，良好症例も少ない結果であった。転帰良好 例が少ない理由として, 発症前 $\mathrm{mRS} 4$ が 2 人, mRS 3 が 3 人 (他科術後での院内発症 1 例, 他院から搬送されてき た 1 例, 発症時 NIHSS 20 点以上で ASPECTS 10 と臨床 症状と画像に乘離がある症例 3 例) と, 80 歳以上群に発症 前 $\mathrm{mRS}$ が悪い例が含まれていたことが挙げられる。この 5 例に扔いては, 発症時平均 NIHSS 21.2, 発症 24 時間後 平均 NIHSS 20 点と症状改善はそしく, カテーテル治療に 関連しない周術期合併症は肺炎 3 例，心不全 1 例が認めら れた。 90 日後の mRS 4 が 1 例 $(20 \%) ， 5$ が 3 例 (60\%)，6 が 1 例 (20\%)であり, その後の経過で 5 例中 3 例が死亡し ていた. 80 歳以上群で発症前 mRS 2 以下だった症例に 限って検討した結果，発症時平均 NIHSS 20.3，発症 24 時
間後平均 NIHSS 16.4 点と直後の症状改善はそしく, カ テーテル治療に関連しない周術期合併症は肺炎 2 例, 尿路 感染 2 例, 心不全 2 例が認められた. 90 日後の mRS 2 以 下が 2 例 $(18.2 \%), 3-5$ が 9 例 $(81.8 \%), 6$ が 0 例 $(0 \%)$ で あった. 80 歳未満群の mRS 2 以下だった症例に比べる と, 転帰不良であったが, 発症前 $\mathrm{mRS} 3$ 以上の症例を含 めなければ，転帰の改善につながることが示された。 Powers $ら^{10)}$ は発症前 mRS 0, 1 の症例を推奨しており, 当院での結果からも発症時の全身状態が不良である症例で は転帰改善がそしいことが示された，院内発症例や，他院 からの紹介例であっても, 発症前 $\mathrm{mRS}$ が悪い例では特に 周術期合併症率が高いことから, 全身状態を十分検討した うえで治療選択する必要があると考えられた。

今回リハビリテーションの有効性指標として 30 日後と 90 日後の $\mathrm{mRS}$ の推移を評価したところ, $\mathrm{mRS}$ が 1 以上 改善した症例は 80 歳以上群で少なく, リハビリテーショ ン病院に転院しても 80 歳以上群では mRS の改善が得ら れにくいことが示唆された.

\section{結 語}

80 歳以上の高齢者に対する血管内血栓回収術の治療成 績を検討した. 80 歳未満と比較すると, 再開通までの時 間や手技時間に有意な差はみられなかったが，転帰良好例 が少ない結果であった。 80 歳以上群では全身合併症率が 高く，そのことが予後に大きく関連していた８８歳以上 に打いても急性期血栓回収療法は有効な治療法である が, 術前の全身状態を十分考慮したうえで, 適応を判断す べきと考えられた。 
本論文は第 46 回日本脳卒中の外科学会で発表した.

著者全員は日本脳神経外科学会への COI 自己申告を完

了しています。本論文の発表に関して開示すべき COI は

ありません。

\section{文献}

1) Berkhemer OA, Fransen PS, Beumer D, et al: A randomized trial of intraarterial treatment for acute ischemic stroke. $N$ Engl J Med 372: 11-20, 2015

2) Campbell BC, Mitchell PJ, Kleinig TJ, et al: Endovascular therapy for ischemic stroke with perfusion-imaging selection. N Engl J Med 372: 1009-1018, 2015

3) Cohen JE, Gomori JM, Leker RR: Stent Retriever-Based Thrombectomy in Octogenarians. Interv Neurol 5: 111-117, 2016

4) Goyal M, Demchuk AM, Menon BK, et al: Randomized assessment of rapid endovascular treatment of ischemic stroke. $N$ Engl J Med 372: 1019-1030, 2015

5) Goyal M, Menon BK, van Zwam WH, et al: Endovascular thrombectomy after large-vessel ischaemic stroke: a metaanalysis of individual patient data from five randomised trials. Lancet 387: 1723-1731, 2016

6) Hwang K, Hwang G, Kwon OK, et al: Endovascular Treatment for Acute Ischemic Stroke Patients over 80 Years of
Age. J Cerebrovasc Endovasc Neurosurg 17: 173-179, 2015

7) Jovin TG, Chamorro A, Cobo E, et al: Thrombectomy within 8 hours after symptom onset in ischemic stroke. $N$ Engl $J$ Med 372: 2296-2306, 2015

8) Lima A, Haussen DC, Rebello LC, et al: Endovascular Therapy for Large Vessel Stroke in the Elderly: Hope in the New Stroke Era. Cerebrovasc Dis 42: 421-427, 2016

9) Parrilla G, Carreon E, Zamarro J, et al: Recanalization and mortality rates of thrombectomy with stent-retrievers in octogenarian patients with acute ischemic stroke. Cardiovasc Intervent Radiol 38: 288-294, 2015

10) Powers WJ, Derdeyn CP, Biller J, et al: 2015 American Heart Association/American Stroke Association Focused Update of the 2013 Guidelines for the Early Management of Patients With Acute Ischemic Stroke Regarding Endovascular Treatment: A Guideline for Healthcare Professionals From the American Heart Association/American Stroke Association. Stroke 46: 3020-3035, 2015

11) Saver JL, Goyal M, Bonafe A, et al: Stent-retriever thrombectomy after intravenous t-PA vs. t-PA alone in stroke. $N$ Engl J Med 372: 2285-2295, 2015

12) Son S, Kang DH, Hwang YH, et al: Efficacy, safety, and clinical outcome of modern mechanical thrombectomy in elderly patients with acute ischemic stroke. Acta Neurochir (Wien) 159: 1663-1669, 2017 